\title{
Female cinema musicians in Sweden 1905-1915
}

Christopher Natzén

Recollecting her time as a musician at the cinema Nya Biografen in Nässjö in southern Sweden, the pianist Elvira Lindeberg gave the following description of working conditions in the early 1910s:

'It was quite hard work, being a pianist a pianist,' says Miss Elvira Lindeberg in Nässjö. 'The night before the premiere we were able to see the film in order to select suitable piano pieces for it. Then I had to fit those to the film's action ... In addition, you had to provide some sound effects. When someone knocked on a door or fired a gun I knocked on the piano or opened and closed the piano lid hard. In the latter case, a bass drum could also be used if we had access to one. What did it matter that the shots came a long time after the gun smoke and sounded like a small nuclear bomb, when the audience was so entranced that not even a grenade explosion would have broken the illusion.'

In a few sentences Lindeberg described her job providing a musical accompaniment and sound effects for moving images. From picking appropriate music and fitting it to the images in order to support the narrative to providing illustrative sound effects, meticulous planning was needed if she was to establish a filmic illusion of reality. And all this work was carried out under time pressure.

That it was a woman who uttered these words about music and 
sound effects is not surprising. Women have always formed a part of the film workforce, and cinema musicians were no exception. In the past decade, researchers have shed light on women's work in film beyond being actresses. ${ }^{2}$ However, judging by historiographies of film music, it is still mainly a story seen through the lens of Lindeberg's male colleagues. ${ }^{3}$ Descriptions of dealing with bad working conditions and long hours in cinemas have been made from a male perspective. Male voices have also expressed views on what kind of music should be used and how to best accompany a film. In that sense Lindeberg's recollections are an exception to the rule. ${ }^{4}$

Looking at the membership of the Swedish Musicians' Union (Svenska musikerförbundet), it is evident that from the time of its foundation in 1907 the union counted many women among its members. Not all of them worked in cinemas, but it was a fact that when the cinema orchestras grew in size many of them employed female musicians. Some women reached the position of conductor and musical director, which would have been an impossibility if they had not mastered their trade. While sons of musicians in the early twentieth century often found positions in the leading orchestras, their daughters often found employment in cinemas. ${ }^{5}$

Today, our understanding of the part women played in shaping Swedish cinema music culture is clouded by the fact that when cinema moved from a low-brow popular entertainment format to a more professionalized programming culture in permanent venues, cinema music practice also became more organized. The Swedish Musicians' Union had a central role in the increasingly standardized musical accompaniment. At the board level, the union was an all-male club that organized work and set policies. As I will argue, this meant that the female musicians' impact has been omitted from histories of film music, despite forming a large part of the development of the music culture in Swedish cinemas.

This essay trains the spotlight on female musicians in cinema's formative years. At this stage it is not possible to give a detailed description, but I hope to show it is possible to tell fresh stories about musical accompaniment, and that there are numerous traces 
that point towards a different understanding of the cinema music culture, at least in Sweden. Beginning with a brief description of Swedish musical life in the early twentieth century in general and film music in particular, I survey what is known today about Swedish cinema music culture. I demonstrate the erroneousness of many contemporary accounts and later academic writing on Swedish film music because they exclude and downplay female musicians- $\mathrm{a}$ constant trend since the earliest writings on cinema music culture, upheld by later research. The sheer extent of the exclusion can be traced to specific archives, illustrating the challenges of archival research. However, as I will argue, it is possible to present a broader and more inclusive account of cinema music culture, if only researchers were prepared to consult alternative sources.

\section{Early cinema music culture}

In the nineteenth century, the distinction between professionals and amateur musicians grew sharper. ${ }^{6}$ The structure of symphonies and piano sonatas began to evolve towards greater complexity and extended length. Instrumental music and lieder came to be perceived as the highest aesthetic form of music. This 'serious' music was contrasted with more popular songs and performances from, for example, the music hall scene. ${ }^{7}$ This dualism became very significant for the development of cinema music in Sweden, which saw popular melodies mixed with nineteenth-century instrumental music, the former initially to draw crowds to the new medium, the latter to add artistic value to the performances a few years later, in an effort to improve cinema's initial reputation as low-brow entertainment.

Women's importance for Swedish musical life in the early decades of the twentieth century was reflected in a decision about terms of employment by the Concert Association (Konsertföreningen) in Gothenburg, which sheds light on the union's policies. On 3 April 1908 it was decided that 'On the question of women for the orchestra, the board agrees that they should have salaries equal to the male members. ${ }^{8}$ This decision was met with criticism, and 
at an extraordinary board meeting on 8 April it was followed up with a clarification, which explained that the decision would not apply retroactively, and that currently employed 'women should remain in the lowest pay grade.' The two decisions show that from its founding in 1907 the union divided up the musicians it represented according to gender.

One feature of culture at the turn of the last century was otherwise its silence. If you did not play music yourself, did not have a gramophone, and were not visited by street musicians, your everyday life-unless you frequented a church, café, restaurant, or other public establishment-would be characterized by a musical silence that can be hard to understand today. It also meant a different way of listening than we have become accustomed to-people listened more intently whenever music was heard. ${ }^{10}$ Places where films were screened became locations for experiencing music, and arguably such places were soon the most important music venues.

Predominantly, the accompaniment to early film screenings consisted of live music, often in the form of a piano or a violin. The gramophone, phonograph, and other kinds of mechanical accompaniment were also in regular use. In Sweden the gramophone in particular was popular on and off throughout the period that we today call the silent era. During the transition to sound film in the late 1920s, several sound systems also came to rely on the technology behind the gramophone, as illustrated by the first commercially viable system, Western Electric's Vitaphone.

It is clear from contemporary sources that some musicians in the early twentieth century just played any kind of music that they knew, regardless of a film's narrative context, thereby giving early film accompaniment a bad reputation. ${ }^{11}$ For example, in 1912, the musicians at the Maxim cinema in Luleå are said to have used for the beginning of each screening a Swedish popular melody called Eldgaffeln ('The Poker') by Einar Landén, followed by a waltz. The same music was subsequently used for the film and between acts, screening after screening, night after night. ${ }^{12}$ In contrast, musicians such as Elvira Lindeberg understood the importance 
of appropriate musical accompaniments, ensuring the music supported the narrative, thus strengthening the cinematic illusion. In other words, some cinema musicians quickly picked up the practice already established in variety entertainment of choosing melodies to follow the unfolding narrative; others used music in a way that was more detached and unrelated to the image content. The latter has dominated descriptions of early cinema accompaniment in Sweden, and because it has been routinely paraphrased in both contemporary writing and later academic scholarship, this image of cinema music lives on. Lindeberg's reasoning about appropriate music and how to match it to the images has thus had to give way to anecdotes like this one from the autobiography of the author and jack of all trades Waldemar Hammenhög:

It was a film based on Anton Dvořák’s 'Humoresque' [about] a little chap who obtained a violin by force from his stingy father and went on to become a great violinist. The film was good, but it was prescribed that we were only allowed to play 'Humoresque' for the whole screening. It became damned tiresome, four hours a night, and on Sunday eight with the matinée. ... But one night, the last Wednesday screening in the fifth week, there was a boozer in the theatre who suddenly screamed at me, 'Don't you know any other piece, you bugger?' Then the audience woke up! Then the audience was listening ... at last there was someone who had listened to the actual piece of music. ${ }^{13}$

While it is difficult to draw any definitive conclusions from Elvira Lindeberg's and Waldemar Hammenhög's recollections, the quotes cited in this essay show that the nature of early cinema music did not just depend on the skill of the musicians. It was rather a question about who knew the trade and understood the musical particularities of the film medium-what did or did not work musically in a cinematic context in terms of tempo, rhythm, and harmonics. Additionally, looking at contemporary writings, it seems as though only male musicians were asked to express their opinions on how 
music might be appropriately used at film screenings, even though many women musicians were involved in film music performances.

With the establishment of permanent premises, there was a shift in musical practice in Sweden. With fixed venues, both the films and their presentation were subject to new requirements from audiences. The skills of particular musicians could be an advantage in the competition with other cinemas. But it also placed greater demands on the musicians. Whereas the musicians in the itinerant exhibitors' heyday performed with the same film day after day in different locations, the establishment of permanent venues involved rapid changes of programming. There could be several different programmes in a single week, making it more difficult to prepare a well-planned accompaniment, and it was no longer acceptable to repeat the same music night after night.

In these years, the Musicians' Union's objectives included tariffs and musical standards. As film professionals sought to increase the reputation of cinema entertainment, there was also a move to standardize cinema music. Cinema should be cinema and not a variety show, as an editorial in the journal Nordisk Filmtidning put it in 1909. ${ }^{14}$ The union favoured the music that in the nineteenth century had been deemed 'serious'. By 1909, cinemas in Malmö were listed in an official tariff. ${ }^{15}$ This had every cinema as being equal in size; later tariffs, however, would be rated according to the number of seats. The salary the union demanded in Malmö was 150 kronor a month (roughly €830 in today's money). Although musicians worked seven days a week and received no wages in the summer months when cinemas were closed, relatively speaking this was a high salary. In comparison, theatre musicians were paid 135 kronor a month according to the same tariff. The figures could be interpreted as a sign that the union as early as 1909 saw cinemas as one of the most important establishments for their members, surpassing theatres. 


\section{Recollections of cinema music culture}

On 19 December 1907 the Swedish Musicians' Union was founded. Typically, a photograph from the founding meeting only portrays men around the table. ${ }^{16}$ Even though the union's membership almost immediately became more heterogeneous, there was no woman on the board. True, the union represented every group of practising musicians, from musicians employed by concert houses to military bands and, of course, cinema musicians, but nevertheless this photograph had little to do with the reality of film music practice in Sweden at that stage. On the other hand, it illustrates very well what happened when musical praxis in Swedish cinemas became increasingly standardized and the musicians organized.

One difficulty when exploring female musicians' contribution to cinema music culture in Sweden is the nature of the sources. For example, the surviving correspondence and minutes of the Swedish Musicians' Union are an important source when researching cinema musicians' working conditions, since they provide evidence on many issues, such as how many musicians worked in cinemas and what was seen in general as appropriate music, as well as giving details of everyday work. In this material men are more than present, and considering the many female members of this union they are strangely absent from the archive materials.

I have gone through the existing documentation from the national union as well as the branches in Gothenburg and Stockholm for 1907 to 1932 . Regardless of archive, it all has one thing in common-female musicians are for the most part not present in the material. Why? I will raise three interrelated answers to this question. First, the surest way to end up in the union's correspondence was to be involved in something that went against union regulations. In short, you needed as a musician to have done something wrong in order to attract the attention of the union. Women members who were good workers and followed regulations might therefore only be listed in the membership registers. Second, those who were mentioned in the records were generally members who were 
able to make their presence felt at union meetings, making sure that union representatives saw their arguments as worthy of being transcribed-not necessarily an easy task for women in the early twentieth century. Third, we should consider the process of appraisal that guided which records were saved at each specific archive. The criteria used to decide what should be archived reflected what was deemed important for posterity. In this particular situation the people in power who took up space-literally in the photograph from the union's founding-and whose actions were considered worth discussing, and hence worth saving, were all men. Women's experiences made visible in a collection held by a male-controlled union, such as the decisions made by the Gothenburg branch in April 1908 mentioned at the start of the essay, were therefore an exception to the rule. Our understanding of women's contributions to the ongoing development of music in the cinemas is further clouded by contemporary and later recapitulations of the 'miserable' music, and reactions from the musicians' community to such claims.

It would be a decade into the new century before cinema music began to be mentioned in periodicals and newspapers, and when it did, it was the noise that was highlighted. In 1909 Nordisk Filmtidning wrote about the woeful music heard in Stockholm cinemas:

It is more a rule than an exception that the piano is out of tune. If the pianist does something, he most often thumps the keys violently; he clearly does not have any ability, or, if he has, makes little effort to show it. ${ }^{17}$

The same article noted that it would be of benefit to cinema owners to improve the music. Good music, it was argued, could even cover other flaws in a venue. The author argued that piano accompaniments should be replaced by a small string orchestra, while stressing the various automated instruments available if in doubt. However, the author gave no further description of cinema music, other than asserting that it was bad. This raises several questions. For example, which cinemas had the author visited? It is true that in 1909 the 
most common practice was accompaniments by a lone pianist or violinist, but the move towards ensembles was already underway, exemplified by the Gothenburg cinema Göteborgs Kinematograf, which for a few weeks in March 1908 used an ensemble of five musicians. ${ }^{18}$ Lindeberg's explanation quoted earlier also showed that other ways to accompany films were already known. It is illustrative that this writer used the pronoun 'he' for the person responsible for the 'noise'. Naturally, it is dangerous to make general claims from an anonymous article, which was one of only few on the topic from the period. We do not know who the author was, and thus nothing about his or her understanding of film music. I would argue, though, that in this instance it is possible to claim an influence from the formation of the Musicians' Union and its gendered perspective. In writings about musical accompaniments in Sweden, 'musicians' became synonymous with male musicians. This can be seen in articles in the entire silent period.

It might be tempting to suggest that the reason behind the lack of female musical experience in contemporary writings was the lack of female musicians. How erroneous such an argument would be, however, is particularly evident when looking at cinema programmes, because in such materials, female musicians are frequently named. I have surveyed close to 10,000 programmes from across Sweden, covering the years 1904 to 1920 , and just a few examples of women mentioned as responsible for the musical accompaniment in the programmes in this collection suffice to show that they were numerous: Anna Ternow at the Valhallabiografen in Oskarshamn, 1909-1910; Agda Söderbergh, Kalmarbiografen in Kalmar, 1913; Mrs Clementz, Scalabiografen in Gävle, 1910-1911; Miss Signe Björklund, Stora Biografen in Eskilstuna, 1911; Mrs G. Hjorth, Linköpings Elektrobiograf in Linköping, 1911; Ellen Swensson, Visby Biografteater in Visby, 1912; Ingeborg Kahl, Visby Biografteater in Visby, 1912; Miss Wiberger, Elektrobiografen in Katrineholm, 1913; Miss A. Baresch, Röda Kvarn in Umeå, 1914; Mrs Ninni Bech-Rehmnes, Röda Kvarn in Umeå, 1914; and Anna Lindgren, Bollnäsbiografen in Bollnäs, 1916. ${ }^{19}$ 
Finally, when the same periodical, Nordisk Filmtidning, summarized 1909, it reported on a marked improvement in the music, keeping pace with cinema developments in general—and contradicting the earlier quote. ${ }^{20}$ Similarly, an article in the journal Filmbladet in 1916 described the development of film music in the previous few years as a constant transformation. ${ }^{21}$ Gone were the out-oftune pianos, as well as the electric instruments that this author associated with early cinema music praxis. Music's most important feature in a cinema was instead its ability to match the images in order to enhance them. The Filmbladet article noted that all this had been driven by the audience, supporting the argument Rick Altman makes in 'Film Sound-All of It'. ${ }^{22}$ Music was given as a partial explanation for the cinema culture's rapid development at the theatre's expense, a claim supported by the 1909 Malmö tariff mentioned above.

The individuals who were invited to comment on the article in Filmbladet were both men: Rudolf Sahlberg, musical director at the Röda Kvarn cinema in Stockholm and Adolf Baumert, conductor at the Imperial cinema, also in Stockholm. Sahlberg considered it important for a conductor to choose music from both the symphonic repertoire and popular melodies according to the audience's taste. He gave the music an interpretive function with the freedom to contradict what the images showed. According to Sahlberg, music was especially useful when creating a film's atmosphere. Baumert largely confirmed what Sahlberg described, adding that it was only with the establishment of permanent venues such as Röda Kvarn in the Sveasalen theatre in 1912 (a different Röda Kvarn to the one where Sahlberg worked) that a new era began. ${ }^{23}$ Both Sahlberg and Baumert thus described a similar music practice as the one explained by Elvira Lindeberg.

The absence of comments from female musicians in this article was not exceptional. Whenever cinema music's function and motivation was discussed in periodicals, it was always male musicians who were asked to comment. This assertion is based on a study of every issue of the main Swedish film and music periodicals in the period: 
Nordisk Filmtidning (1909-1910), Svenska musikerförbundets tidning (1910-1919), Biografen (1913-1915), Filmbladet (1915-1925), Filmnyheter (1920-1929), Biografbladet (1920-1952), Musikern (1920-), Svensk Filmtidning (1924-1939), and Biografägaren (1926-1966). In all of these issues, not a single woman was allowed to present her point of view on cinema music. The conductor Greta Håkansson, who worked at the Påfågeln cinema, was given a biographical and honorary article in Musikern in $1928 .{ }^{24}$ But she was not asked to comment on musical practice, nor was it her musical skills that were highlighted, even though she had been playing in cinemas since at least $1915 .{ }^{25}$ Instead, much was made of her loyalty to union policies and regulations - the editor, Gustaf Gille, seemed to find it necessary to place emphasis on this in order to justify the inclusion of her biography in the publication.

The lack of interest in or disregard of women musicians' work is mirrored and further illustrated in later academic writing. In 1979, the film historian Rune Waldekranz wrote an article about the development of musical accompaniment. ${ }^{26}$ The essay gives a general description about film music accompaniment in the silent period, drawing mainly on the work of Roy Prendergast. ${ }^{27}$ The sections about Swedish circumstances rely on Waldekranz's own research. The article begins by arguing that early exhibitors in the period 1896-1906 primarily used the gramophone as a means to provide accompaniment in Sweden. Waldekranz's narrative is that from this period onwards, gramophones were followed by live music with lone pianists and travelling virtuosos, but the development of permanent venues ushered in the standardization of music practice and larger ensembles. Together with longer films, the music then also became more intricately fitted to the film. In establishing this, the article follows our understanding of the larger development of Swedish musical culture. However, by focusing on virtuosos in the early period, Waldekranz misses that the culture of cinema music was one created by ordinary musicians; instead, he leaves the reader with the impression that a succession of male musicians and directors were the pioneering developers of cinema 
music in Sweden. Many of the lesser-known musicians whose contribution Waldekranz ignores were women. By looking at the cinema programmes mentioned in this essay it is clear that women's contribution to the field was just as extensive as that of the men who hold Waldekranz's attention.

\section{Conclusion}

The 'silent era' was not a period of unbroken, repetitive musical accompaniment. Instead it was characterized by a diversity of musical practices. For some musicians, the music was rather a part of a film's exhibition than an integrated aspect of the film itself. Often the smallness of an ensemble or the presence of a solitary pianist only underlined certain aspects of the narrative rudimentariness. Other musicians worked according to the principles set out by Elvira Lindeberg, and with the introduction of permanent cinemas demands were raised, both concerning the content of the films and how they were presented.

Despite the important function of music and sound in helping an audience become absorbed in a film, one obstacle to research, and particularly research on female musicians, has been that such fundamental music practices were seldom mentioned in reviews. Accompanying music was seen as such an evident part of the screening practice that it was not considered newsworthy enough to write about. And when the function of cinema music was discussed in trade publications it was not women who were asked to voice their opinion; the musicians who were permitted to contribute to the discussion were all men. Women have arguably also been misrepresented in histories of the development of a cinema music culture in Sweden.

I wrote in my introduction that if researchers were willing to consult alternative sources, such as the cinema programmes discussed in this essay, a different and more inclusive vision of cinema music would appear. This would eventually lead to a rewriting of the history of cinema music culture in Sweden. The programmes 
are a useful source that helps form a more complete picture of the period 1905 to 1914 . If nothing else, the source material shows that women were accompanying moving images as well as working as musical directors in cinemas. However, when comments about the musical practice in cinemas became more common, often stressing the poor quality of the music, the response was to change the cinema programming. The programmes started to use expressions such as 'good', 'high quality', and 'excellent' to describe the music an audience could expect to hear in the cinema. Unless an outstanding musician was going to make a guest appearance, the musicians themselves were no longer mentioned. This makes it even harder to research women's contributions to cinema music culture after 1914. As programmes increasingly failed to mention the names of the musicians, and as female musicians were not mentioned in or allowed to voice their opinion in periodicals, and left few if any traces in the Musicians' Union's archive, they literally disappeared from the history of Swedish cinema music.

\section{Notes}

1 Ray 1949, 3. All translations are by the author unless otherwise noted.

2 See, for example, the Women Film Pioneers project (https://wfpp.cdrs.columbia. edu/) and Nordic Women in Film (http://www.nordicwomeninfilm.com/), discussed elsewhere in this volume in Stigsdotter's introduction, Åhlund's foreword, and Hanssen's essay 'Visible absence, invisible presence: Feminist film history, the database, and the archive'.

3 The focus in Sweden and elsewhere has been on the role and function of music, rather than on the practising musicians, and therefore discussions have centred on descriptions of the music, rather than questioning the extent to which such claims apply to both genders.

4 For this article, all film journals from the period have been reviewed as well as the Musicians' Union's archives from the main board and from the union departments in Stockholm and Gothenburg respectively. These sources have one thing in common-female cinema musicians are generally not represented in the material.

5 Edström 2009, 20-1.

6 Grout \& Palisca 1988, 662.

7 Edström 2009, 59-60; Grout \& Palisca 1988, 659. 
8 Landsarkivet i Göteborg (Regional State Archives in Gothenburg), Svenska musikerförbundet, Sektion 2, Göteborg, Protokoll från styrelsesammanträde, 3 April 1908, \$3 (Swedish Musicians’ Union, minutes of the Gothenburg board).

9 Landsarkivet i Göteborg, Svenska musikerförbundet, Sektion 2, Göteborg, Protokoll från extra sammanträde, 8 April 1908, $\$ 6$ (Swedish Musicians' Union, minutes of an extraordinary meeting).

10 Edström 2009, 39.

11 'Musikens anpassande för filmen' 1920, 213-14.

12 'Från "rörliga bilder" till Cinemascope' 1956, 10, 13.

13 Hammenhög 1942, 92-3.

14 'Vårt program' 1909, 4.

15 Edström 1982, 17.

16 Ibid. 32.

17 'Musiken å biograferna' 1909, 2.

18 Advertisement for Göteborgs Kinematograf in Göteborgs-Posten, 13 March 1908, 1.

19 All programmes can be accessed at https://biografblad.kb.se/or http://filmarkivforskning.se/, both accessed 16 June 2019.

20 'En återblick' 1910, 1.

21 'Biografmusik' 1916, 349-50.

22 Altman 1999, 31-48.

23 The Röda Kvarn in Sveasalen had 867 seats, making it a leading cinema in the city. Established in 1912, it initially employed 12-14 musicians under the direction of Gustaf Erbs (Berglund 1993, 309). The Röda Kvarn where Sahlberg was conductor was established in 1915 and had 14 musicians. Sahlberg became its conductor in 1916 and held the position until the arrival of sound film (Berglund 1993, 307-308).

24 Gille 1928, 336-7.

25 Advertisement for the film Ned med vapnen in Aftonbladet, 1 December 1915, 4.

26 Waldekranz 1979, 179-99.

27 Prendergast 1992.

\section{References}

Aftonbladet, 1 December 1915: 4 [advertisement for the film Ned med vapnen]. Altman, Rick, 'Film Sound-All of It', Iris, 27 (1999): 31-48.

Berglund, Kurt, Stockholms alla biografer: Ett stycke Stockholmshistoria från 9o-tal till 9o-tal (Stockholm: Svenska Turistföreningen, 1993).

'Biografmusik', Filmbladet, 2/24, 18 December 1916: 349-50.

Edström, Karl-Olof (Olle), På begäran: Svenska Musikerförbundet 1907-1982 (Stockholm: Tidens förlag, 1982). 
- - 'Sång och musik: Förr och nu', in id. (ed.), Säg det om toner och därtill i ord: musikforskare berättar om 1900-talets musikliv (Stockholm: Carlsons förlag, 2009). 'En återblick', Nordisk Filmtidning, 2/19, January 1910: 1-2.

Gille, Gustaf, 'En kvinnlig biografkapellmästare', Musikern, 21/23, 1 December 1928: 336-7.

Göran, 'Från "rörliga bilder" till Cinemascope', Norrbottens-Kuriren, 10 November 1956: 10-13.

Göteborgs-Posten, 13 March 1908: 1 [advertisement for Göteborgs Kinematograf].

Grout, Donald J. \& Claude V. Palisca, A History of Western Music (4th edn, London: W. W. Norton, 1988).

Hammenhög, Waldemar, Det var en gång en musiker (Stockholm: Wahlström \& Widstrand, 1942).

Landsarkivet i Göteborg (Regional State Archives in Gothenburg), Svenska musikerförbundet, Sektion 2, Göteborg, Protokoll från styrelsesammanträde, 3 April 1908, \$ 3 (Swedish Musicians’ Union, minutes of the Gothenburg board).

Landsarkivet i Göteborg (Regional State Archives in Gothenburg), Svenska musikerförbundet, Sektion 2, Göteborg, Protokoll från extra sammanträde, 8 April 1908, $\$ 6$ (Swedish Musicians' Union, minutes of an extraordinary meeting).

'Musiken å biograferna', Nordisk Filmtidning, 1/9, August 1909: 1-2.

'Musikens anpassande för filmen', Musikern, 13/21, 1 November 1920: 213-14.

Prendergast, Roy M., Film Music: A Neglected Art-A Critical Study of Music in Films (London: W.W. Norton, 1992) (first pub. 1977).

Ray, 'Trettiotalet—guldålder för biograferna i Nässjö, Nässjötidningen, 4 February 1949: 3 .

'Vårt program', Nordisk Filmtidning, 1/1 (1909): 3-4.

Waldekranz, Rune, 'Stumfilmens musik', in Brolinson, Per-Erik (ed.), Skriftfest: 19 uppsatser tillägnade Martin Tegen på hans 60-årsdag den 28 april 1979 (Stockholm, Stockholms universitet, Musikvetenskapliga institutionen, 1979): 179-199. 